appears the essence of acts of empathy, then the constitution of the psycho-physical individual, and lastly, empathy as the comprehension of mental persons. To students of Husserl it will seem remarkable how well Edith Stein has mirrored the master's aversion from psychologism, namely the insidious intrusion of purely subjective tenets into domains essentially logical. This volume is not very likely to appeal to experimental scientists, but it has significance for them if they explore the field of 'personal knowledge' as Polanyi has conceived it.

On the level of human experience, there can be little doubt that the attainment of a high degree of empathy is something which can bo recognized as akin to a species of genius. An obvious examplo is the fusion of the wholo personality of a great actor with that of his hero, or even with situations encountered by him. Less potent, but equally intriguing, are the cases in which master and pupil havo shared a common intellectual quest, reaching perhaps a common goal. In these instances agreement is not nocessary at all stages of the journey; what is important is that the thread of 'in-feeling' should never be strained beyond the elastic limit. It appears that empathic potential can build up substantially, and maybe lead to a break-through in discovery, or to the birth of new ideas.

Even in the workaday world, history produces vestiges of empathic reactions when, for example, an artist has exceptional respect for and understanding of his materials and so is likely to bring about a result of greater sensibility than one lacking, or largely lacking, in this quality. The phrase 'mastery over materials' is often heard and is misleading if it connotes coercion into inappropriate uses. Indeed, one of tho outstanding features of a great work of art is the perfect fitness of the substances involved in reaching the final cause (in tho Aristotelian sense) which the artist had in mind.

In briof, the background of this investigation is strictly phenomenological, which, however, does not destroyin fact it onhances-its value to the philosophical psychologist. It is impossible to waive (in the manner of Husserl's (reduction') sensations. They are just as surely given as judging, willing and perceiving.

A word of appreciation is due to the translator, who is a grand-neice of Edith Stein. She has reproduced the spirit of the thesis well, although there are one or two lapses from idiomatic English. An excellent point is the marginal pagination of the original text. Edith Stein served with tho Red Cross in World War I and experienced empathy in the field; she was to live to write her great Kreuzeswissenschaft later on, and to seal it with her death. F. I. G. Rawlins

\section{NUTRITIONAL VALUE OF PROTEINS}

Valeur Nutritionnelle des Protéines

Symposium organisé le 15 Novembre 1962 sous l'Egide de la Délégation Générale à la Recherche Scientifique et Techniquo. (Annales de Biologie Animale, Biochimie, Biophysique, Vol. 3, Numéro Hors-sério 1.) Pp. 133. (Paris: Institut National de la Recherche Agronomique, 1963.) 11.50 francs.

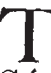
HIS small volume contains the papors read at a symposium held under the auspices of the Délégation Générale à la Recherche Scientifiquo et Technique in Paris during November 1962. It contains some twenty papors organizod in seven sections, and reflects work carried out on nutritional aspects of proteins in a numbor of research laboratories throughout Franco during 1961 and 1962 .

In the first section there is a report of work carried out at the Metabolism Laboratory of the Institut National de la Recherche Agronomique on the amino-acid composition of proteins in animal and human foods, using the chromatographic technique of Moore and Stein.

Some new techniques are reported in the section on the digestion of proteins and the intestined absorption of amino-acids. Because of the importance of the correct balance of amino-acids arriving simultaneously at the point of protein synthesis, the rate of digestion of protein was investigated, the distribution in the alimentary tract of the pig being determined at intervals; followed by an interesting account of work on the changes in amino-acid concentration in the portal vein during digestion. The use of different methods of estimation of protein quality was considered. For example, the microbiological method of Ford, using Streptococcus zymogenes, was found to give satisfuctory correlation only for animal foods, not for soya oil-cake.

The effect of heat-processing of herring meal used for animal feeding was next considered at the symposium. The fish-moal heated at $60^{\circ}, 90^{\circ}$ and $130^{\circ} \mathrm{C}$ was examined in different laboratories by various methods: there was not, howevor, agreement on the degree of protein damage at different temperatures. One laboratory reported on the romarkable ability of a small supplement of fish protein in quadrupling the rate of growth of rats being fed with gluten as the source of protein in the feed.

The significance of the ratio of calories to protein was emphasized in the next section, in which the work of various laboratories led to the view that the biological value of the proteins is an important factor, affecting the spontaneous caloric intake of both rats and chicks is growth experiments. The protein value of various African foods was considered, in relation to the fight against kwashiorkor in West Africa. These foods included threo types of African beans, and the traditional methods of preserving fish were also reviewed.

This useful symposium concluded with three papers concerned with biochemical aspects of proteins: the rolationship betwoen the significance of gliadin in coeliac disease; the isolation of a-lactalbumin from cows' milk; and investigations of glyco-proteins in human and cows' millk.

The organizers are to bo congratulated on this valuable contribution to our understanding of the subject-the book will bo of great interest to all workers in the field.

M. SPENCER

\section{NEUTRON DIFFRACTION}

The International Encyclopedia of Physical Chemistry and Chemical Physics

Topic 11: The Ideal Crystalline State, Vol. 1: Applications of Noutron Diffraction in Chemistry. Edited by M. Blackman. Pp. xi+141. (Oxford, London, New York and Paris: Pergamon Press, 1963.) $42 s$.

7

THE de Broglie wavo-length of a thermal noutron, that is, a neutron tho kinetic energy of which corresponds to room temperature, is of the order of a few Angströms, which is about the same as the distance betwoen atoms in a solid or liquid. Thus neutrons may bo used, just like $\mathrm{X}$-rays, to provide information about the structure of solids and liquids. As they have no charge neutrons cannot be accelerated or focused; honce it is necessary to start with a poworful source for diffraction experiments. Such sources have become available in the past two decados with the advent of the nuclear reactor.

Unlike X-rays, which are scattered by the electrons in the atom and which are, therefore, only scattered weakly by atoms of small atomic numbor, neutrons are scattered mainly by the nucleus itsolf. The scattering from different nucloi varies in an irregular manner throughout the Periodic Table. It is this difference which makes neutrons such a useful complement to X-rays. In particular, the 